\title{
PERUBAHAN SIFAT FISIKO-KIMIAWI SELAMA PROSES FERMENTASI BIJI KAKAO SEGAR
}

\section{(Changes in Physical-Chemical Properties During The Fresh Cocoa Fermentation Process)}

\author{
Nandi K. Sukendar ${ }^{1 *}$, Abu Bakar Tawali ${ }^{1)}$, Salengke $^{2)}$, Adiansyah Syarifuddin ${ }^{1)}$, Andi \\ Hasizah Mochtar ${ }^{1)}$, dan Andi Fakhruddin ${ }^{3)}$ \\ ${ }^{1 *}$ Dosen Prodi Studi Ilmu dan Teknologi Pangan, Fakultas Pertanian, Universitas Hasanuddin, Indonesia \\ ${ }^{2)}$ Dosen Prodi Studi Keteknikan Pertanian Unhas, Makassar, Indonesia \\ ${ }^{3)}$ Balai Besar Karantina Pertanian Makassar, Indonesia \\ ${ }^{*}$ Email Penulis Korespondensi: Nandiks@ Agri.Unhas.Ac.Id
}

\begin{abstract}
ABSTRAK
Kakao merupakan komoditas perkebunan yang membutuhkan proses fermentasi untuk memperbaiki mutu citarasa dan aromanya. Penelitian tentang perubahan profil sifat fisikokimia selama proses fermentasi spontan biji kakao segar untuk skala berat 20, 40 dan $60 \mathrm{~kg}$ telah dilakukan. Penelitian ini bertujuan untuk memperoleh informasi sebagai indikator tingkat keberhasilan proses fermentasi biji kakao segar, baik pada skala kecil maupun besar. Proses fermentasi berlangsung selama 6 hari dengan pengadukan dimulai pada hari kedua hingga hari keenam, dengan selang waktu 24 jam. Rancangan penelitian menggunakan metode rancangan acak kelompok (RAK) pola petak terpisah dengan 2 faktor, yaitu skala berat biji per kotak dan waktu fermentasi dengan tiga kali ulangan. Data yang diperoleh dianalisa secara kualitatif dan kuantitatif. Berdasarkan indikator parameter yang diamati, yaitu suhu, $\mathrm{pH}$ dan total asam, tidak terdapat perbedaan nyata profil perubahan sifat fisiko-kimia selama proses fermentasi berlangsung diantara ketiga tingkat skala berat tersebut. Kondisi sifat fisiko-kimia tersebut memperlihatkan hubungan yang lurus dengan mutu biji kakao fermentasinya, sesuai dengan hasil cut testnya.
\end{abstract}

Kata Kunci: biji kakao, fermentasi, pH, suhu, dan total asam.

\section{ABSTRACT}

Cocoa is a plantation commodity that requires fermentation to improve the quality of flavor and aroma. Research on changes in physical and chemical properties during the spontaneous fermentation process of fresh cocoa beans for weight scales of 20, 40 and $60 \mathrm{~kg}$ have been carried out. This study aims to obtain information as an indicator of the success rate of the fermentation process of fresh cocoa beans, both on a small and large scale. The fermentation process lasts for 6 days with stirring starting on the second day until the sixth day, with an interval of 24 hours. The study design uses a randomized block design method (RBD) with two factors, namely the weight scale of seeds per box and fermentation time with three replications. The data obtained were analyzed qualitatively and quantitatively. Based on the observed parameter indicators, namely temperature, $\mathrm{pH}$ and total acid, there was no significant difference in the profile of the physico-chemical properties during the fermentation process between the three weight scale levels. The physico-chemical condition shows a straight relationship with the quality of fermented cocoa beans, in accordance with the results of the cut test.

Keywords: cocoa beans, fermentation, temperature, $\mathrm{pH}$ and total aci 


\section{PENDAHULUAN}

Perubahan sifat fisiko-kimiawi seperti suhu, $\mathrm{pH}$ dan total asam selama proses fermentasi berlangsung merupakan indikator yang penting dalam pendugaan tingkat keberhasilan suatu proses fermentasi, baik untuk skala kecil maupun besar. Indikator tersebut dapat secara murah, mudah dan praktis untuk diamati di lapangan.

Salah satu kriteria utama mutu kakao yang dapat digunakan sebagai bahan baku di industri pangan yaitu biji kakao harus terfementasi dengan baik. Biji kakao yang tidak termentasi dengan baik akan menghasilkan produk olahan yang bermutu rendah, baik dari segi rasa maupun aromanya(Langkong, Mahendradatta, M Tahir, Abdullah, \& Reski, 2019). Fermentasi terjadi pada dua tahap yaitu tahap anaerobik dan aerobik. Tahap anerobik terjadi pada keadaan tidak ada oksigen, sedangkan tahap aerobik terjadi pada keadaan membutuhkan banyak oksigen. Tingkat aktivitas mikroba anaerobik maupun aerobik sangat bergantung pada ketersediaan nutrisi dan sumber karbon bawaan maupun hasil metabolit (alkohol dan asam laktat) biji kakao yang difermentasi.

Keberhasilan suatu proses fermentasi biji kakao segar ditentukan oleh tingkat kemasakan buah dan lama waktu fermentasi. Selain itu, jumlah minimal biji yang difermentasi berpengaruh terhadap perubahan profil sifat fisiko-kimiawi mutu biji kakao fermentasi berdasarkan hasil uji cut test. Pengolahan tepat yang diperoleh kemudian diaplikasikan di tingkat petani, khususnya pada skala $20 \mathrm{~kg} /$ boks.

\section{METODOLOGI PENELITIAN}

\subsection{Alat}

Alat-alat yang digunakan pada proses fermentasi adalah box fermentasi (sterofoam) untuk skala ukuran $20 \mathrm{~kg}, 40$, $\mathrm{kg}$ dan $60 \mathrm{~kg}$ serta thermometer digital. Sedangkan, alat-alat yang digunakan untuk analisis parameter adalah $\mathrm{pH}$ meter, timbangan analitik dan spektrofotometer

\subsection{Bahan}

Bahan-bahan yang digunakan pada proses fermentasi adalah biji kakao dari Pinrang berupa biji basah dan biji kering. Sedangkan, bahan-bahan yang digunakan pada analisis parameter adalah $\mathrm{NaOH} 0,1$ $\mathrm{N}$, fenoftalin, aquadest, kertas saring, metanol 97\%, dan $\mathrm{HCl} 3 \%$.

\subsection{Prosedur Penelitian}

Rancangan penelitian dilakukan dengan metode rancangan acak lengkap (RAK) pola petak terpisah. Faktor pertama adalah waktu fermentasi (F) yang terdiri dari hari ke-2 $\left(\mathrm{F}_{2}\right)$, hari ke-3 $\left(\mathrm{F}_{3}\right)$, hari ke-4 $(\mathrm{F} 4)$, hari ke-5 $\left(\mathrm{F}_{5}\right)$ dan hari ke-6 $\left(\mathrm{F}_{6}\right)$. Faktor kedua adalah berat biji per kotak fermentasi (B) yang terdiri dari $20 \mathrm{~kg}\left(\mathrm{~B}_{1}\right)$, $40 \mathrm{~kg}\left(\mathrm{~B}_{2}\right)$, dan $60 \mathrm{~kg}\left(\mathrm{~B}_{3}\right)$.

Table 1. Rancangan Penelitian

\begin{tabular}{cccc}
\hline $\begin{array}{c}\text { Waktu } \\
\text { (hari) }\end{array}$ & \multicolumn{3}{c}{ Skala Berat } \\
\hline 2 & $\mathrm{~A}_{2} \mathrm{~B}_{1}$ & $40 \mathrm{~kg}$ & $60 \mathrm{~kg}$ \\
\hline 3 & $\mathrm{~A}_{2} \mathrm{~B}_{2}$ & $\mathrm{~A}_{2} \mathrm{~B}_{3}$ \\
4 & $\mathrm{~A}_{4} \mathrm{~B}_{1}$ & $\mathrm{~A}_{3} \mathrm{~B}_{2}$ & $\mathrm{~A}_{3} \mathrm{~B}_{3}$ \\
5 & $\mathrm{~A}_{5} \mathrm{~B}_{1}$ & $\mathrm{~A}_{5} \mathrm{~B}_{3}$ & $\mathrm{~A}_{5} \mathrm{~B}_{3}$ \\
6 & $\mathrm{~A}_{6} \mathrm{~B}_{1}$ & $\mathrm{~A}_{6} \mathrm{~B}_{2}$ & $\mathrm{~A}_{6} \mathrm{~B}_{3}$ \\
\hline
\end{tabular}

\subsection{Tahap Penelitian}

\subsubsection{Pemilihan Buah Kakao}

Bahan baku yang digunakan berasal dari klon yang sama, diperoleh dari kelompok tani kakao Bukit Tinggi-Desa Tapoorang-Kecamatan BatulappaKabupaten Pinrang-Sulsel. Klon yang digunakan pada penelitian ini S2 atau Sulawesi 2, petani umumnya menyebut sebagai klon 25. Tingkat kematangan buah seragam pada tingkat kematangan A. Jumlah biji kakao basah yang diperlukan 
pada penelitian ini sebanyak $360 \mathrm{~kg}$ untuk 3 kali ulangan.

\subsubsection{Penentuan Wadah (Volume) Box}

Wadah yang digunakan pada penelitian ini berbahan sterofoam. Dimensi wadah yang digunakan yaitu 51 x 40 x 32 $\mathrm{cm}^{3}$ untuk $20 \mathrm{~kg} ; 75$ x 40 x $32 \mathrm{~cm}^{3} 40 \mathrm{~kg}$; dan 120 x 40 x $32 \mathrm{~cm}^{3}$ untuk $60 \mathrm{~kg}$.

\subsubsection{Pengumpulan dan penimbangan Biji Kakao}

Buah kakao yang diperoleh dari beberapa petani dikumpulkan dan disortasi sesuai kriteria (jenis dan tingkat kematangan). Setelah itu, dilakukan pemecahan buah kakao untuk mengeluarkan dan memisahkan biji kakao dari kulit buah dan plasentanya. Biji kemudian ditimbang secara keseluruhan, lalu dilakukan pengacakan. Selanjutnya, dibagi rata sesuai dengan perlakuan (B) pada setiap box.

\subsubsection{Fermentasi}

Fermentasi berlangsung selama 6 hari dan mulai dilakukan pengadukan pada akhir hari kedua hingga hari keenam dengan selang waktu 24 jam. Sampel biji kakao dibilas dengan air mengalir untuk menghilangkan bahan terlarut yang menempel pada biji.

\subsubsection{Pengeringan}

Pengeringan dilakukan dengan menggunakan cahaya matahari langsung di atas lantai jemur secara terpisah sesuai dengan perlakuan. Saat cuaca cerah lama penyinaran 7-8 jam per hari. Waktu penjemuran \pm 7 hari untuk mencapai kadar air maksimal $7,5 \%$.

\subsubsection{Pengambilan Sampel}

Sampel sebanyak sekitar 300 biji untuk analisis diperoleh dari biji kakao yang telah difermentasi dan dikeringkan. Pengambilan sampel dilakukan pada hari ke-2, hari ke-3, hari ke-4, hari ke-5 dan hari ke-6 setelah pengukuran suhu dan sebelum pengadukan sebanyak $1 \mathrm{~kg}$. Sampel yang didapatkan dibawa ke laboratorium untuk di analisis

\subsection{Parameter Penelitian}

\subsubsection{Pengukuran Suhu}

Pengukuran suhu dilakukan 6 jam sekali. Pada fase anaerob suhu diukur 6-48 jam, sedangkan pada fase aerob suhu diukur 54-120 jam. Termometer dimasukkan ke dalam lubang, lalu ditunggu hingga menunjukkan angka yang stabil.

\subsubsection{Penentuan pH (BSN, 2008)}

Mula-mula dilakukan kalibrasi pada pH meter. Timbang contoh uji sebanyak \pm $10 \mathrm{~g}$ ke dalam gelas piala, lalu dihaluskan. Kemudian dtambahkan $25 \mathrm{ml}$ aquadest, aduk perlahan-lahan sampai homogen. Selanjutnya, diukur menggunakan $\mathrm{pH}$ meter.

\subsubsection{Total Asam}

Pengukuran total asam tertitrasi dilakukan dengan prinsip titrasi asam basa. Sebanyak $10 \mathrm{~g}$ sampel dimasukkan ke dalam labu ukur diencerkan dalam $100 \mathrm{~mL}$, kemudian dipipet sebanyak $25 \mathrm{~mL}$ ke dalam erlenmeyer. Lalu ditambahkan dengan tiga tetes indikator fenoftalin. Sampel kemudian ditambahkan dengan $\mathrm{NaOH} 0,1 \mathrm{~N}$. Titrasi dihentikan jika warna berubah menjadi merah muda. Perhitungan total asam $(\%)$ yaitu:

volume $\mathrm{NaOH}$ x N NaOH x FP x BM asam organik x 100

berat bahan $\times 1000$

\subsubsection{Uji Cut Test (Aryani, 2018)}

Sebanyak 50 biji kakao dibelah membujur tepat dibagian tengahnya menjadi dua dengan ukuran yang sama besar. Dari 100 belahan biji tersebut diamati satu per satu warna keping biji kakao berdasarkan klasifikasinya (SNI 012323-2008). Pada penelitian ini dilakukan klasifikasi menjadi 3 kelas dimana warna slaty (berwarna ungu agak keabu-abuan 
dan bertekstur pejal) dimasukkan ke dalam kelas biji unfermented, warna ungu dominan terhadap cokelat ke dalam kelas biji underfermented, dan cokelat dominan masuk kelas biji fermented.

\subsection{Pengolahan Data}

Data yang diperoleh dari penelitian ini diolah dengan menggunakan Microsoft excel 2013. Analisis data dengan menggunakan analisis sidik ragam (ANOVA), jika terdapat perbedaan nyata akan dilakukan uji lanjut dengan menggunakan uji lanjut BNJ dan Duncan.

\section{HASIL DAN PEMBAHASAN}

\subsection{Suhu}

Suhu merupakan parameter yang menandakan terjadinya proses fermentasi oleh suatu mikroorganisme. Mikroorganisme tersebut memanfaatkan gula dan asam sitrat dalam pulp menjadi asam-asam organik yang lebih sederhana. Proses fermentasi berlangsung secara anaerobik dan aerobik dengan jenis mikroba aktif berbeda; Pada keadaan anaerobik didominasi oleh khamir yang bersuksesi dengan bakteri asam laktat (BAL), sedangkan pada dominasi bakteri asam asetat (BAA) pada keadaan aerobik (Apriyanto, Sutardi, Supriyanto, \& Harmayani, n.d.). Hasil pengukuran suhu pada fase anaerobik disajikan pada Gambar 01.

\subsubsection{Fase Anaerob}

Fermentasi fase anaerobik berlangsung sekitar 48 jam pertama; Pada kondisi tersebut khamir mendominasi aktivitas pertumbuhan dan kemudian disusul oleh aktivitas pertumbuhan BAL. Perubahan suhu selama fase tersebut disajikan pada Gambar 1.

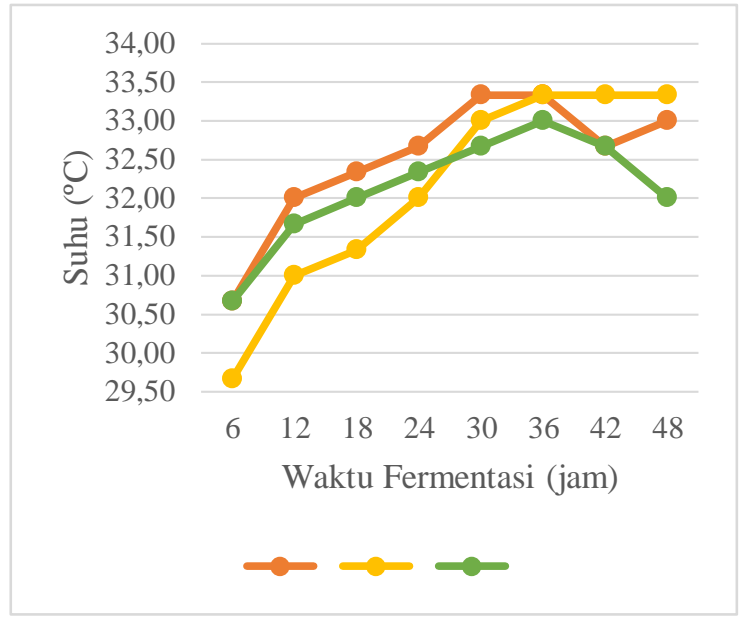

Gambar 1. Perubahan suhu selama fermentasi anaerobik pada ketiga skala berat biji kakao yang difermentasi.

Pada 30 jam pertama secara umum terjadi peningkatan suhu fase anaerob (Gambar 1). Namun, saat waktu 36-42 jam pada skala $20 \mathrm{~kg}$ dan $60 \mathrm{~kg}$ mengalami penurunan dengan nilai selisih rata-rata secara berturut-turut yaitu 0,66 dan 0,33 . Pada skala berat $20 \mathrm{~kg}$ mengalami kenaikan suhu kembali pada akhir fase anaerob (48 jam) dengan nilai $33^{\circ} \mathrm{C}$, sedangkan pada skala berat $60 \mathrm{~kg}$ terus mengalami penurunan pada akhir fase anaerob (48 jam) dengan nilai $32^{\circ} \mathrm{C}$. Saat waktu 36-48 jam pada skala $40 \mathrm{~kg}$ mempunyai nilai rerata suhu yang konstan yaitu $33,33^{\circ} \mathrm{C}$. Waktu $6-48$ merupakan fase anaerobik, pada fase ini khamir akan mengkonversi gula menjadi alkohol dalam kondisi rendah oksigen. Mikroorganisme yang berperan dalam fase ini yaitu S.cerevisiae yang tumbuh dengan suhu optimum $30-35^{\circ} \mathrm{C}$. Hal ini sesuai dengan penelitian yang dilakukan oleh (Apriyanto et al, 2017 ), bahwa populasi S.cerevisiae naik dari $10^{2}-10^{6} \log \mathrm{CFU} / \mathrm{g}$ menjadi $10^{7}$ $\log$ CFU/g setelah fermentasi 24 jam pertama. Penurunan suhu yang stabil memungkinkan adanya pertumbuhan bakteri asam laktat (BAL). BAL tumbuh dominan pada hari ke-2 fermentasi dan akan berkurang seiring dengan 
peningkatan suhu. Menurut penelitian yang dilakukan oleh Purwanto et al (2019), bahwa BAL berada pada fase kedua suksesi mikrob fermentasi kakao, yaitu 2472 jam fermentasi.

\subsubsection{Fase Aerob}

Perubahan suhu selama proses fermentasi pada fase aerobik diamati pada tiga posisi bagian, yaitu bagian Atas, Tengah dan Bawah boks fermentasi. Hasil pengukuran suhu pada masing-masing bagian tersebut diperlihatkan oleh gambar 2, gambar 3 dan gambar 4, secara berurutan.

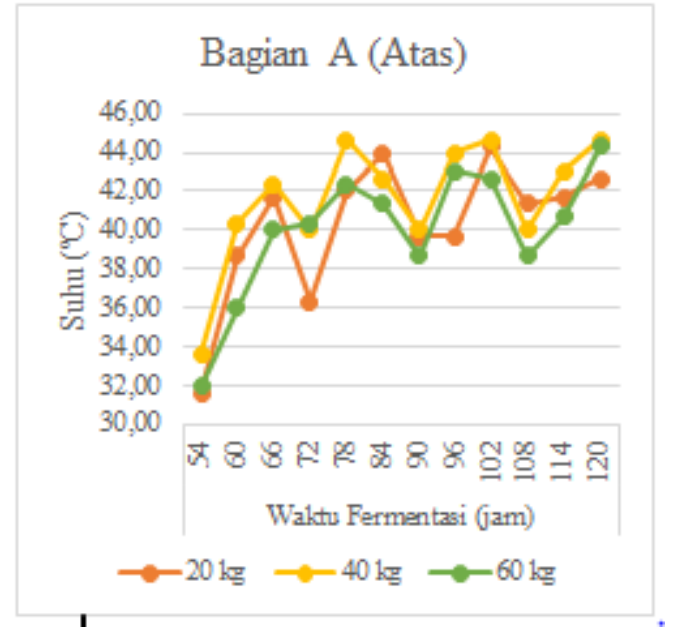

Gambar 2. Perubahan suhu selama fermentasi aerobik pada posisi Atas untuk ketiga skala berat biji kakao yang difermentasi.

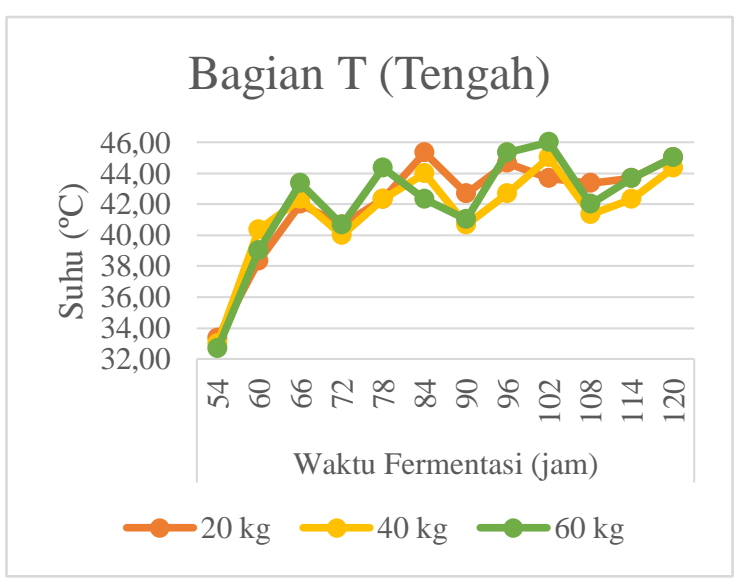

Gambar 3. Perubahan suhu selama fermentasi aerobik pada posisi Tengah untuk ketiga skala berat biji kakao yang difermentasi.

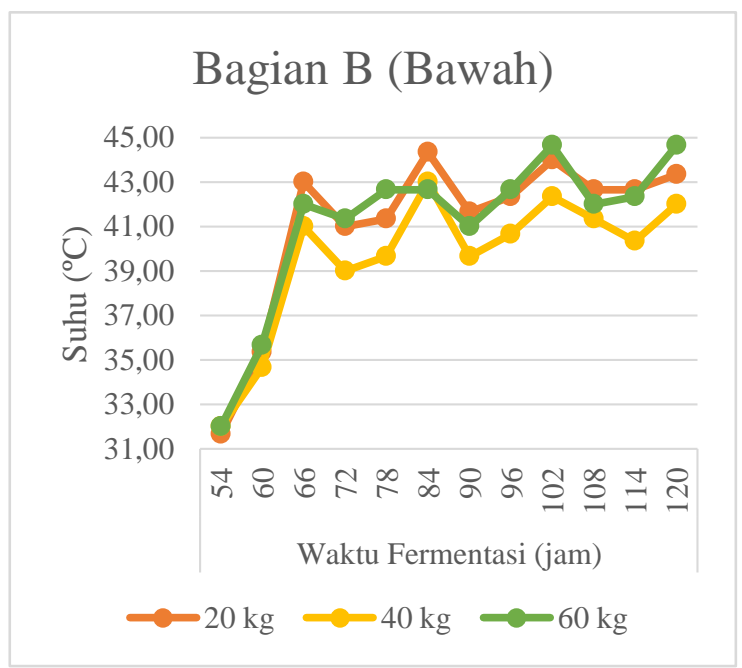

Gambar 4. Perubahan suhu selama fermentasi aerobik pada posisi Bawah untuk ketiga skala berat biji kakao yang difermentasi.

Perubahan suhu cenderung fluktuatif pada semua posisi (Gambar 2 sampai Gambar 4). Peningkatan suhu disebabkan panas yang timbul saat fermentasi aerob berlangsung karena adanya reaksi oksidasi yang membutuhkan oksigen. Menurut Tarigan (2018), menyatakan dalam kondisi aerob, bakteri asam asetat aktif mengoksidasi alkohol menjadi asam asetat, sehingga menghentikan aktivitas khamir dan bakteri asam laktat dengan suhu tumpukan biji kakao mencapai $42-52^{\circ} \mathrm{C}$. Penurunan suhu terjadi pada waktu 72, 90, dan 108 jam disebabkan panas yang keluar setelah dilakukan pengadukan. Menurut Arnawa (2013), bahwa pengadukan yang dilakukan setiap hari, akan terjadi over aerasi, sehingga akan kehilangan panas terlalu besar, mengakibatkan suhu $45^{\circ} \mathrm{C}$ tidak tercapai. Selain itu, rasio pulp memungkinkan untuk mempeengaruhi proses aerasi pada fermentasi. Menurut Arnawa (2013), bahwa biji dengan jumlah pulp lebih banyak akan membatasi pertukaran udara. 


\section{$3.2 \mathrm{pH}$}

Nilai pH merupakan parameter untuk menentukan tingkat keasaman biji kakao fermentasi. Keasaman berasal dari asam organik yang terbentuk akibat reaksi metabolisme pada saat proses fermentasi berlangsung (Sabhannur, 2017). Hasil analisa $\mathrm{pH}$ disajikan pada Gambar 5.

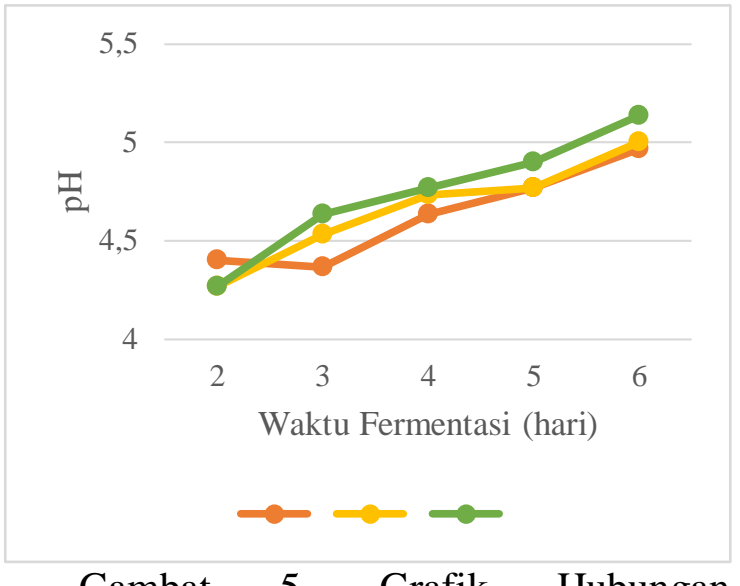

Gambat 5. Grafik Hubungan Parameter $\mathrm{pH}$ dengan Skala Berat dan Waktu Fermentasi.

Hasil analisa $\mathrm{pH}$ pada biji kakao selama fermentasi menunjukkan bahwa pada skala berat $20 \mathrm{~kg} \mathrm{pH}$ cenderung meningkat mula-mula yaitu 4,4 pada fermentasi hari ke-2 kemudian menurun di fermentasi hari ke-3 menjadi 4,37 dan kembali meningkat pada fermentasi hari-4 hingga fermentasi hari ke-6 dengan nilai $\mathrm{pH}$ diakhir fermentasi yaitu 4,97. $\mathrm{pH}$ biji kakao fermentasi pada skala berat $40 \mathrm{~kg}$ mengalami peningkatan dari 4,27 pada fermentasi hari ke-2 terus meningkat hingga diakhir fermentasi dengan nilai $\mathrm{pH}$ 5. Adapun pada skala berat $60 \mathrm{~kg}$ nilai $\mathrm{pH}$ terus meningkat dari 4,27 pada fermentasi hari ke-2 hingga diakhir fermentasi dengan nilai $\mathrm{pH}$ 5,13. Pulpa segar memiliki kandungan gula yang tinggi dan $\mathrm{pH}$ rendah dikarenakan asam sitrat. Fase awal pada proses fermentasi biji kakao yaitu fase anaerobik. Fase anaerobik tepat untuk pertumbuhan khamir. Khamir akan mengubah pulp segar menjadi alkohol dan menghasilkan karbon dioksida serta air. Terurainya pulp menyebabkan sebagian besar asam sitrat berkurang karena mengalir bersama cairan fermentasi. Kondisi ini mengakibatkan peningkatan $\mathrm{pH}$ dan perubahan suhu yang mendorong pertumbuhan BAL. Menurut Utami (2018), bakteri asam laktat yang terlibat adalah jenis homofermenter yang mengkonversi glukosa menjadi asam laktat serta heterofermenter yang memproduksi asam laktat dan juga alkohol, asam asetat dan karbondioksida.

\subsection{Total Asam}

Selama fermentasi mikroorganisme akan menguraikan gula menghasilkan alkohol dan asam organik. Produksi asam penting dalam proses fermentasi karena asam akan berdifusi ke dalam biji dan selanjutnya menginduksi reaksi biokimia yang menyebabkan biji kakao

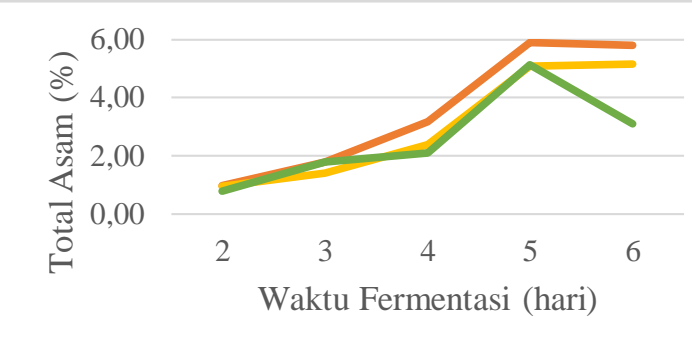

terfermentasi sempurna (Apriyanto et al, 2017).

Gambat 6. Grafik Hubungan Parameter Total Asam dengan Skala Berat dan Waktu Fermentasi.

Hasil analisa total asam pada biji kakao selama fermentasi menunjukkan bahwa skala berat $20 \mathrm{~kg}$ pada fermentasi hari ke-2 mempunyai nilai 1,03 terus meningkat hingga fermentasi hari ke-4 dengan nilai 3,37, namun pada fermentasi hari ke-5 mengalami penurunan menjadi 3,01 dan terus menurun hingga 2,96 pada fermentasi hari ke-6. Skala berat $40 \mathrm{~kg}$ pada fermentasi hari ke-2 mempunyai nilai total asam 1,00 yang terus mengalami peningkatan hingga fermentasi hari ke-6 dengan nilai 2,63. Adapun pada skala 60 
$\mathrm{kg}$ mempunyai nilai 0,84 pada fermentasi hari ke-2 yang mengalami peningkatan hingga fermentasi hari ke-5 dengan nilai 2,63 , namun mengalami penurunan pada fermentasi hari ke-6 menjadi 1,58. Menurut Nirwana (2017), menyatakan bahwa adanya peningkatan total asam disebabkan terbentuknya asam-asam organik seperti asam asetat dan asam laktat. Pada akhir fermentasi, tiap-tiap perlakuan mengalami penurunan total asam diduga dikarenakan larutnya sebagian asam galakturonat pada cairan pulp. Hal ini sesuai dengan yang dinyatakan oleh Putra et al (2009), bahwa setelah terjadi peningkatan total asam selanjutnya mengalami penurunan walaupun proses depolimerisasi pektin pulp terus berlangsung, karena sebagian asam galakturonat maupun asam organik lain yang terbentuk, terdispersi dalam cairan pulp yang ikut menetes keluar.

\subsection{Cut Test}

Cut test merupakan parameter yang digunakan untuk melihat keberhasilan fermentasi biji kakao dari segi warna. Warna biji kakao tanpa fermentasi yaitu berwarna ungu, sedangkan warna biji kakao yang terfermentasi berwarna coklat (Misnawi et al, 2003).

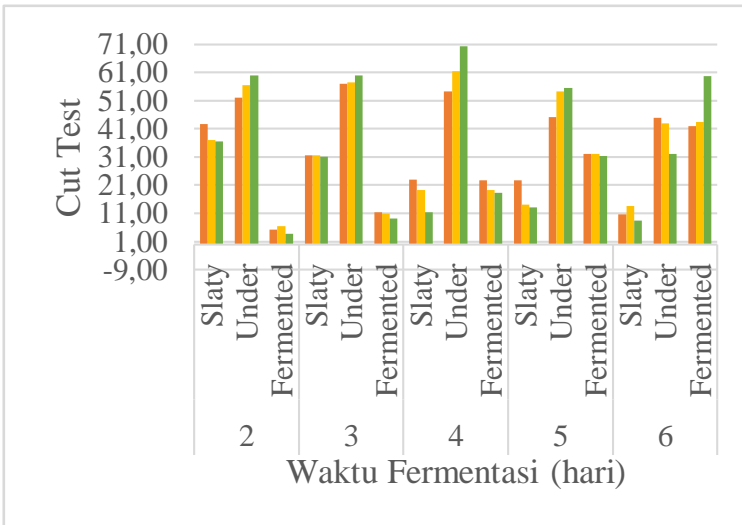

Gambar 7. Grafik Hubungan Parameter pH dengan Skala Berat dan Waktu Fermentasi.

Hasil menunjukkan nilai biji slaty terbesar terdapat pada fermentasi hari ke-2 dengan nilai rata-rata $36-43 \%$. Semakin lama waktu fermentasi maka biji slaty akan semakin menurun menjadi $8-14 \%$ pada fermentasi akhir. Namun saat fermentasi hari ke-5 pada skala $60 \mathrm{~kg}$ mengalami kenaikan dari fermentasi hari ke-4 dengan nilai $11,33 \%$ menjadi $13,17 \%$. Nilai biji underfermented pada skala $20 \mathrm{~kg}$ mengalami kenaikan saat fermentasi hari ke-3 dari 52\% menjadi 57\%, setelahnya mengalami penurunan hingga akhir fermentasi menjadi $44,83 \%$. Pada skala 40 $\mathrm{kg}$ nilai biji underfermented mengalami kenaikan dari fermentasi hari ke-2 hingga fermentasi hari ke-4 dengan nilai 56,50\% menjadi $61,50 \%$, lalu mengalami penurunan hingga fermentasi hari ke-6 menjadi 42,83\%. Skala $60 \mathrm{~kg}$ mempunyai nilai biji underfermented yang sama pada fermentasi hari ke-2 dan hari ke-3 yaitu $59,83 \%$, kemudian meningkat pada fermentasi hari ke-4 menjadi 70,33\%, lalu menurun hingga fermentasi hari ke-6 dengan nilai $32 \%$. Nilai biji fermented terendah pada fermentasi hari ke-2 dengan nilai rata-rata $3-7 \%$, semakin lama waktu fermentasi nilai biji fermented terus meningkat hingga fermentasi hari ke-6 dengan nilai rata-rata 41-60\%. Menurut Diansari et al (2016), bahwa selama fermentasi polifenol akan teroksidasi oleh enzim polifenol oksidase dengan membentuk senyawa polifenol kompleks yang mengubah biji kakao dari warna ungu menjadi coklat.

\section{KESIMPULAN}

1. Berdasarkan hasil analisa pati ubi jalar ungu dengan variasi penambahan asam askorbat menunjukkan bahwa kandungan antosianin pati ubi jalar ungu lebih rendah jika Berdasarkan sifat fisikokimia yang diamati, yaitu suhu, $\mathrm{pH}$ dan Total Asam, dapat disimpulkan bahwa tidak terdapat perbedaan nyata diantara ketiga perlakuan skala berat biji kakao segar yang difermentasi (20, 40 dan $60 \mathrm{~kg} /$ boks). 
2. Ketiga sifat fisikokimia tersebut adalah berkorelasi positif terhadap parameter umum mutu biji kakao hasil fermentasinya, yakni berdasarkan hasil Cut Test dan nilai persentasenya tidak berbeda nyata pada ketiga skala berat biji kakao segar yang difermentasi.

3. Waktu fermentasi berpengaruh terhadap suhu, $\mathrm{pH}$, total asam, dan cut test waktu fermentasi terbaik terjadi pada fermentasi hari ke-6.

\section{UCAPAN TERIMA KASIH}

Paper ini ditulis berdasarkan sebagian data hasil penelitian yang didanai oleh Program Hibah Internal UNHAS TA 2019 berdasarkan SK Rektor UNHAS No. 641/UN4.1/KEP/2019-Tanggal 4 Februari 2019.

Ucapan terima kasih kami sampaikan kepada Sdri Hanifah Muthiah (G311115513), mahasiswi tugas akhir yang telah membantu kami dalam pekerjaan penelitian.

\section{DAFTAR PUSTAKA}

Apriyanto, M., Sutardi, S., Supriyanto, S., \& Harmayani, E. (n.d.). Fermentasi Biji Kakao Kering Menggunakan Saccharomyces cerevisiae, Lactobacillus lactis, dan Acetobacter aceti. agriTECH, 37(3), 302-311.

Diansari, A. Z., Suwasono, S., \& Yuwanti, S. (2016). Karakteristik Fisik, Kimia dan Mikrobiologis Biji Kakao Kering Produksi PTPN XII Kebun Kalikempit, Bayuwangi. Jurnal Berkala Ilmiah Pertanian, 1(1).

Langkong, J., Mahendradatta, M., M Tahir, M., Abdullah, N., \& Reski, M. (2019). Pemanfaatan Kulit Biji Kakao (Theobroma Cacao L) Menjadi Produk Cookies Coklat. Canrea Journal: Food Techology, Nutritons, and Culinary Journal, 2(1), 44-50. https://doi.org/10.20956/canrea.v2i1.2 11

Misnawi, Jinap, S., Jamilah, B., \& Nazamid, S. (2003). Effects of incubation and polyphenol oxidase enrichment on colour, fermentation index, procyanidins and astringency of unfermented and partly fermented cocoa beans. International Journal of Food Science \& Technology, 38(3), 285-295.

Nirwana, N. (2017). Kajian Pengaruh Berat Biji Kakako Perkotak dan Waktu Pengadukan terhadap Keberhasilan Proses Fermentasi. Jurnal Pendidikan Matematika Dan IPA, 8(2), 18-30.

Purwanto, E. H., Setyabudi, S., \& Supriyanto, S. (2019). Microbial Activities in Cocoa (Theobroma Cacao L.) Pulp During Fermentation With Ragi Tape Addition. Jurnal Tanaman Industri Dan Penyegar, 6(1), 21-32.

Putra, G., Harijono, H., Susanto, S., Kumalaningsih, K., \& Aulanni'am, A. (2009). Optimasi Kondisi Depolimerisasi Pulp Biji Kakao. Jurnal Teknik Industri, 9(1), 45-54.

Tarigan, E. B. (2018). Beberapa komponen fisikokimia kakao fermentasi dan non fermentasi. Jurnal Agroindustri Halal, 3(1).

Utami, R. R. (2018). Antioksidan Biji Kakao: Pengaruh Fermentasi Dan Penyangraian Terhadap Perubahannya (Ulasan). Jurnal Industri Hasil Perkebunan, 13(2), 75-85. 